\title{
Corrigendum: Whole-Transcriptome
} Analysis of Verocytotoxigenic Escherichia coli 0157:H7 (Sakai) Suggests Plant-Species-Specific Metabolic Responses on Exposure to Spinach and Lettuce Extracts

\author{
Louise Crozier ${ }^{1}$, Pete E. Hedley ${ }^{1}$, Jenny Morris ${ }^{1}$, Carol Wagstaff ${ }^{2}$, Simon C. Andrews ${ }^{3}$, \\ Ian Toth ${ }^{1}$, Robert W. Jackson ${ }^{3}$ and Nicola J. Holden ${ }^{1 *}$ \\ ${ }^{1}$ Cell and Molecular Sciences, The James Hutton Institute, Dundee, UK, ${ }^{2}$ School of Chemistry, Food and Pharmacy, The \\ University of Reading, Reading, UK, ${ }^{3}$ School of Biological Sciences, The University of Reading, Reading, UK
}

Keywords: DNA microarray, stress response, E. coli 0157:H7, vegetables, leaves, roots, adaptation, biological

OPEN ACCESS

Edited by:

Christophe Nguyen-The, Institut National de la Recherche

Agronomique, France

Reviewed by:

Maria T. Brandl,

Agricultural Research Service, USA

*Correspondence:

Nicola J. Holden

nicola.holden@hutton.ac.uk

Specialty section:

This article was submitted to

Food Microbiology,

a section of the journal

Frontiers in Microbiology

Received: 02 September 2016 Accepted: 08 September 2016 Published: 21 September 2016

Citation:

Crozier L, Hedley PE, Morris J

Wagstaff C, Andrews SC, Toth I, Jackson RW and Holden NJ (2016) Corrigendum: Whole-Transcriptome

Analysis of Verocytotoxigenic

Escherichia coli 0157:H7 (Sakai)

Suggests Plant-Species-Specific Metabolic Responses on Exposure to

Spinach and Lettuce Extracts.

Front. Microbiol. 7:1506.

doi: 10.3389/fmicb.2016.01506

\section{A corrigendum on}

Whole-Transcriptome Analysis of Verocytotoxigenic Escherichia coli O157:H7 (Sakai) Suggests Plant-Species-Specific Metabolic Responses on Exposure to Spinach and Lettuce Extracts by Crozier, L., Hedley, P. E., Morris, J., Wagstaff, C., Andrews, S. C., Toth, I., et al. (2016). Front. Microbiol. 7:1088. doi: 10.3389/fmicb.2016.01088

In the Introduction to the article, one of the references, Kyle et al. (2010) was included in error in the statement "However, in many reports on plant-colonization transcriptomics the bacteria were initially cultured at body temperature $\left(37^{\circ} \mathrm{C}\right)$ and were subsequently exposed to plant (or plant extracts) at environmental temperature $\left(\sim 18^{\circ} \mathrm{C}\right)$; such experimental regimes result in a considerable temperature shift, in addition to the exposure to plant or plant extracts (Thilmony et al., 2006; Kyle et al., 2010; Hou et al., 2012, 2013; Jayaraman et al., 2014)". Instead, the Kyle et al. study used a temperature of $28^{\circ} \mathrm{C}$ throughout the experiment, for initial culturing of the inoculum and for subsequent bacteria-plant interactions, so that the bacteria did not encounter a temperature shift. An extract from the Methods section is provided below. Erroneous inclusion of this reference in the statement has no impact on the scientific validity of the results presented.

The correct statement is: "However, in many reports on plant-colonization transcriptomics the bacteria were initially cultured at body temperature $\left(37^{\circ} \mathrm{C}\right)$ and were subsequently exposed to plant (or plant extracts) at environmental temperature $\left(\sim 18^{\circ} \mathrm{C}\right)$; such experimental regimes result in a considerable temperature shift, in addition to the exposure to plant or plant extracts (Thilmony et al., 2006; Jayaraman et al., 2014; Hou et al., 2012, 2013)"

Extract of the Methods section from Kyle et al. (2010):

"For experiments measuring early gene expression in lettuce leaf lysate (by microarray and QRT-PCR) or on shredded lettuce (by QRT-PCR), overnight cultures were transferred to fresh M9-glucose and grown for several hours into the mid-log phase of growth at $28^{\circ} \mathrm{C}$ and $150 \mathrm{rpm}$ and then washed twice with KP buffer before inoculation. The lysates were inoculated with EcO157 cells in the mid-log phase of growth in minimal medium in order to isolate the bacterial responses to romaine lettuce lysates from changes in gene expression solely caused by the transition out 
of stationary phase (6). Lysates were inoculated at $5 \times 10^{6} \mathrm{CFU} / \mathrm{ml}$ for growth experiments and at $10^{8} \mathrm{CFU} / \mathrm{ml}$ for microarray analysis and QRT-PCR and then incubated at $28^{\circ} \mathrm{C}$ with shaking at $150 \mathrm{rpm}$. In order to evaluate gene expression in $\mathrm{EcO} 157$ in lettuce lysates, samples for RNA extraction and subsequent microarray or QRT-PCR analysis were taken at 15 or $30 \mathrm{~min}$ after exposure of mid-log-phase EcO157 cells to freshly prepared lysates. Short incubation periods in the lysates at $28^{\circ} \mathrm{C}$ were used in order to characterize the early response of the pathogen to

\section{REFERENCES}

Hou, Z., Fink, R. C., Black, E., Sugawara, M., Zhang, Z., Diez-Gonzalez, F., et al. (2012). Gene expression profiling of Escherichia coli in response to interactions with the lettuce rhizosphere. J. Appl. Microbiol. 113, 1076-1086. doi: 10.1111/j.1365-2672.2012.05412.x

Hou, Z., Fink, R. C., Sugawara, M., Diez-Gonzalez, F., and Sadowsky, M. J. (2013). Transcriptional and functional responses of Escherichia coli O157:H7 growing in the lettuce rhizoplane. Food Microbiol. 35, 136-142. doi: 10.1016/j.fm.2013.03.002

Jayaraman, D., Valdés-López, O., Kaspar, C. W., and Ané, J.-M. (2014). Response of Medicago truncatula seedlings to colonization by Salmonella enterica and Escherichia coli O157:H7. PLoS ONE 9:e87970. doi: 10.1371/journal.pone.0087970

Kyle, J. L., Parker, C. T., Goudeau, D., and Brandl, M. T. (2010). Transcriptome analysis of Escherichia coli O157:H7 exposed to lysates of lettuce leaves. Appl. Environ. Microbiol. 76, 1375-1387. doi: 10.1128/AEM.02461-09 fluids leaking out of leaf cells after injury occurred, at an ambient daytime temperature that would be present in the field during growth and harvesting, or during processing under conditions that would fail to maintain cool temperatures."

\section{AUTHOR CONTRIBUTIONS}

$\mathrm{NH}$ : wrote the correction statement. LC, PH, JM, CW, SA, IT, RJ, and $\mathrm{NH}$ : approved statement.

Thilmony, R., Underwood, W., and He, S. Y. (2006). Genome-wide transcriptional analysis of the Arabidopsis thaliana interaction with the plant pathogen Pseudomonas syringae pv. tomato DC3000 and the human pathogen Escherichia coli O157:H7. Plant J. 46, 34-53. doi: 10.1111/j.1365-313X.2006.02725.x

Conflict of Interest Statement: The authors declare that the research was conducted in the absence of any commercial or financial relationships that could be construed as a potential conflict of interest.

Copyright (C) 2016 Crozier, Hedley, Morris, Wagstaff, Andrews, Toth, Jackson and Holden. This is an open-access article distributed under the terms of the Creative Commons Attribution License (CC BY). The use, distribution or reproduction in other forums is permitted, provided the original author(s) or licensor are credited and that the original publication in this journal is cited, in accordance with accepted academic practice. No use, distribution or reproduction is permitted which does not comply with these terms. 